Participative Journal: Jurnal Pengabdian Pada Masyarakat

Vol. 01, No. 02, September 2021 | Page 93-103

E-ISSN 2776-2971, P-ISSN 2776-5954

Journal homepage: https://jurnal.jurmat.com/index.php/pj/index

\title{
Meningkatkan kualitas bacaan dan hafalan anak melalui inisiatif pemuda dusun Jorong Desa Sikur Barat dalam mendirikan (LTKQ)
}

Aulia Iswaratama ${ }^{1} *$

* Affiliasi: Prodi Sosiologi Agama Universitas Islam Negeri Mataram

\begin{abstract}
$\boldsymbol{A} \boldsymbol{b} \boldsymbol{s} \boldsymbol{t} \boldsymbol{r} \boldsymbol{a} \boldsymbol{c} t$ : The existence of the qur 'an as a living guide is mandatory to be studied and taught for all mankind to have nothing more to gain the degrees of takwa and the salvation of the afterlife.So it is important to give knowledge and education about the qur 'an at an early age as a provision for children to print the generations of the qur 'ani.Early childhood is a golden age that results in rapid growth and growth. To create a generation of the qur 'ani that can understand and memorize the qur 'an, our village's jorong village west of sikur established an institute of tahfidz, and the study of the qur 'an,which is aimed at helping children improve reading and reciting the qur 'an,as well as teaching children basic religious science and educating them to be the ultimate discipline of time.
\end{abstract}

Keywords. Improve the quality of the reading, the quran,an early age

A b s t r a k: Keberadaan al-Qur'an sebagai pedoman hidup wajib untuk dipelajari dan diajarkan bagi seluruh umat manusia tiada lain untuk mencapai derajat takwa dan keselamatan dunia akhirat.Maka penting memberikan pengetahuan dan edukasi tentang al-Qur'an pada anak usia dini sebagai bekal pada anak untuk mencetak generasi Qur'ani.Masa anak usia dini adalah masa keemasan yang merupakan pertumbuhan dan perkembangan sangat pesat. Untuk menciptakan generasi qur'ani yang bisa memahami dan menghafal al-Qur'an kami remaja dusun jorong Desa Sikur Barat mendirikan sebuah Lembaga Tahfidz dan Kajian Al-Qur'an yang bertujuan untuk membantu anak-anak meningkatkan bacaan dan hafalan Al-Qur'an,selain itu kami juga mengajarkan anak-anak ilmu-ilmu agama dasar dan mendidik mereka agar menjadi disiplin terutama disiplin waktu.

Kata kunci: Meningkatkan kualitas bacaan, Al Quran,anak usia dini

\footnotetext{
${ }^{1}$ Coresponden to author: Prodi Sosiologi Agama, Universitas Islam Negeri Mataram, Jl. Gajah Mada Jempong, Indonesia. (83116), e-mail addresses: 180602003.mhs@uinmataram.ac.id
} 


\section{Pendahuluan}

Al-Quran diturunkan di muka bumi sebagai rahmat bagi seluruh alam. Ia juga sebagai tanda dan pengukuhan atas kenabian dan kerasulan nabi Muhammad SAW. Keberadaan Al-Quran sebagai mukjizat yang agung yang didalamnya berisi petunjuk dan pedoman bagi kehidupan manusia dalam segala aspek kehidupan umat manusia sebagai khalifah di muka bumi. Al-Quran berisi pedoman yang mengatur kehidupan manusia dengan penciptanya,manusia dengan sesama manusianya dan manusia dengan alam yang berupa tumbuhan, binatang dan sebagainya. AlQur'an juga merupakan firman Allah yang apabila dibaca dan dihayati maknanya akan menjadi kegiatan ibadah untuk memperbanyak pahala dan mendapatkan banyak sekali manfaat bagi kehidupan dunia dan kehidupan akhirat.Maka mempelajari dan mengajarkan Al-Quran merupakan suatu kewajiban bagi setiap diri umat Islam sebagaimana disebutkan dalam hadis yang diriwayatkan oleh Utsman bin Affan Ra,Rasulullah SAW bersabda:

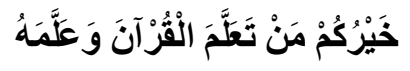

Artinya: Rasulullab SAW bersabda, Sebaik Baik diantara kalian adalah yang mempelajari al-Qur'an dan mengajarkannya.( RA Bukhari Muslim)

Menghafalkan Al-Qur'an merupakan salah satu bentuk interaksi umat Islam dengan AlQur'an yang telah berlangsung secara turun menurun sejak Al-Qur'an pertama kali turun kepada Nabi Muhammad SAW.hingga sekarang dan masa yang akan datang.Allah SWT.telah memudahkan Al-Qur'an untuk dihafalkan,baik oleh umat Islam yang berasal dari Arab maupun selain Arab yang tidak mengerti arti kata-kata dalam Al-Qur'an yang menggunakan bahasa Arab.Tidak bisa dielakkan lagi bahwa dalam sejarah,Al-Qur'an terjaga kemurniannya bukan hanya karena memang sudah ditulis sejak Al-Qur'an diwahyukan,akan tetapi juga karena partisipasi dari para penghafal Al-Qur'an.Al-Qur'an ketika akan dibukukan, dikumpulkan dalam bentuk benda-benda yang memungkinkan Al-Qur'an ditulis pada zaman nabi,seperti pelepah kurma,kepingan tulang dan lempengan-lempengan batu.Lembaran-lembaran Al-Qur'an tersebut tidak diterima kecuali setelah dipersaksikan oleh dua orang saksi yang menyaksikan bahwa ayat Al-Qur'an yang tertulis dalam lembaran tersebut benar ditulis di hadapan Nabi Muhammad SAW.Selain itu, ayat Al-Qur'an tersebut harus dihafal oleh salah seorang sahabat. ${ }^{2}$

Sebagaimana dirangkum oleh Ahsin W.Al-Hafidz, ada beberapa alasan mengapa menghafal Al-Qur'an dianggap sangat penting dilakukan,yakni sebagai berikut. Pertama, AlQur'an diturunkan dan diterima Nabi secara hafalan kemudian diajarkannya kepada sahabat pun dengan hafalan. Kedua, hikmah diturunkannya Al-Qur'an secara berangsurangsur

\footnotetext{
${ }^{2}$ Teguh Arafah Julianto"Metode menghafal dan Memahami Al-Qur'an Bagi Anak Usia Dini”./ IQRO: Journal of Islamic Education Vol. 1, No.1, Juli 2018. 71-84
}

Rahmanita \& Jamhuri (2021), Dampak kebijakan pengalihan.........

| Vol. 01, No.02, 2021 | h. 94 
mengisyaratkan motivasi dan semangat untuk menjaganya melalui hafalan dan memahami kandungannya dengan baik. Ketiga, firman Allah dalam Q.S.al-Hijr:9 bersifat aplikatif, yang berarti bahwa jaminan terpeliharanya kemurnian Al-Qur'an adalah Allah yang memberikannya, akan tetapi tugas operasional secara nyata harus dilakukan oleh umat yang memilikinya, yakni umat Islam. Keempat, menghafal Al-Qur'an mempunyai hukum fardhu kifayah, yang artinya bahwa orang yang menghafal Al-Qur'an tidak boleh kurang dari jumlah mutawatir sehingga tidak akan terjadi kemungkinan pemalsuan, pengurangan atau penambahan terhadap ayat-ayat AlQur'an. Jika kewajiban tersebut sudah terpenuhi, maka gugurlah kewajiban bagi yang lainnya. Adapun, jika tidak terpenuhi, maka umat Islam seluruhnya akan menanggung dosa. ${ }^{3}$

Menghafalkan Al-Qur'an tidak hanya dilakukan oleh orang dewasa, akan tetapi remaja, bahkan anak-anak pun melakukannya dimulai dari sedini mungkin untuk mencetak generasigenerasi qur'ani yaitu generasi yang mencintai dan memahami Al-Quran. Namun kenyataanya, hal tersebut tidak serta merta membuat mayoritas umat Islam tergerak untuk mempelajarinya terlebih lagi menghafalkannya, terkhusus anak anak usia dini yang belum terbiasa memahami AlQur'an.

\section{Metode}

Metode yang digunakan untuk mencapai tujuan yang direncanakan dalam pengabdian adalah metode: 1) gambaran mengenai proses kegiatan pengabdian masyarakat.2) partisipasi action: yaitu kegiatan yang dilakukan dalam bentuk aksi nyata secara lansung saya sebagai salah satu remaja ikut menjadi pengurus di lembaga tahfidz yang didirikan oleh remaja dusun Jorong.3) Edukatif yaitu disini kami juga mengajarkan adek-adek dasar ilmu agama melalui kajian setelah sholat subuh.

\section{Hasil dan Pembahasan}

Desa Sikur Barat adalah desa yang berasal dari pemekaran desa Sikur. Pemekaran ini terjadi karena luasnya wilayah dan desa Sikur juga termasuk salah satu Desa yang cukup maju, maka dari itu masyarakat dan pengurus Desa mulai berdiskusi bagaimana kalau dilakukan pemekaran, tidak lama setelah adanya diskusi itu mulai dilakukan pengumpulan dana, pendataan penduduk, menentukan batas wilayah, pembuatan nama dan luas wilayah yang akan diambil dalam wilayah pemekaran desa sebagai kelengkapan administrasi yang dibutuhkan dalam mengajukan permohonan pemekaran Desa ke Pemerintah Kabupaten Lombok Timur. Dan setelah melakukan diskusi yang kedua akhirnya terpilihlah nama Sikur Barat yang diambil dari

3 Aida Hidayah”Metode Tahfid Al-Qur’an Anak Usia Dini. “.Journal Studi Ilmu-ilmu Al-Qur'an dan Hadits vol.18 no.1 januari 2017

Rahmanita \& Jamhuri (2021), Dampak kebijakan pengaliban.........

| Vol. 01, No.02, 2021 | h. 95 
asal usul Desa sebelum adanya pemekaran yaitu Desa Sikur Barat dan Barat karena Desa ini berada di bagian Barat dengan data sebagai berikut:

a. Jumlah penduduk=4.021 jiwa 905 Kepala keluarga yang terdiri dari 2.000 penduduk lakilaki dan 2.021 penduduk perempuan

b. Luas wilayah $=199,50 \mathrm{Ha}$.

c. Batas wilayah

- Sebelah Barat Desa Montong Baan

- Sebelah Utara Desa Kesik

- Sebelah Timur Desa Sikur

- Sebelah Selatan Desa Semaya

d.Jumlah kekadusan

1) Kekadusan Penyenggir

2) Kekadusan Jorong

3) Kekadusan Endut

4) Kekadusan Tengaing

5) Kekadusan Manggong

B.Fasilitas Desa

1) Kantor Desa

2) Polindes

3) Balai keamanan Desa

4) Lapangan sepak bola

5) Madrasah Ibtidaiyah

6) Taman kanak-kanak,dan

7) Sedang proses pembangunan tempat wisata.

\section{Potensi Desa}

Di Desa Sikur Barat ini para penduduknya 95\% adalah petani karena meskipun ada yang jadi guru, pegawai dan lain-lain, masyarakat tetap melanjutkan profesi tani. Dulu masyarakat lebih banyak yang menanam padi, namun seiring berjalannya waktu para petani lebih tertarik untuk menanam sayur karena untungnya cukup besar dan sangat menjanjikan seperti, kembang kol, bawang merah, cabe hijau, cabe rawit, kacang-kacangan dan masih ada juga petani yang menanam padi. Sejak masyarakat menanam sayur penghasilannya meningkat dan bisa untuk memenuhi kebutuhan sehari-hari bahkan lebih.

Rahmanita \& Jamhuri (2021), Dampak kebijakan pengalihan.........

| Vol. 01, No.02, 2021 | h. 96 
Untuk budaya dan potensi keagamaan masyarakat Didesa saya ini masih melestarikan budaya nenek moyang mereka namun,ada juga yang sudah tidak digunakan dan untuk hal agama adalah hal paling penting,sehingga sebagian besar orang tua di desa Sikur Barat menyekolahkan anaknya ke sekolah yang berbasis agama seperti Pondok pesantren.Selain itu masyarakat di desa Sikur Barat terkenal memiliki tingkat sosial yang tinggi,terkenal ramah walaupun dengan orang baru.Untuk tetap melestarikan potensi agama di salah satu dusun di desa Sikur Barat yaitu dusun Jorong didirikan sebuah lembaga AL-Qur'an atau TPQ. ${ }^{4}$

TPQ adalah salah satu bentuk dari banyaknya lembaga pendidikan keagamaan islam yang hidup subur di tengahtengah masyarakat.Hampir di setiap komunitas muslim terdapat lembagalembaga ini,dan selama ini pula lembaga-lembaga tersebut telah banyak berperan dalam pengembangan masyarakat.Perkembangan lembaga pendidikan Al-Quran yang begitu pesat menandakan makin meningkatnya kesadaran masyarakat akan pentingnya kemampuan baca tulis Al-Quran.Keberadaan pendidikan Al-Quran membawa misi yang sangat mendasar terkait dengan pentingnya memperkenalkan dan menanamkan nilai-nilai Al-Quran sejak usia dini.Keberadaan TPA/TPQ mempunyai potensi dan pengaruh yang sangat besar dalam pertumbuhan pendidikan keagamaan,karena TKQ dan TPQ berperan besar dalam membangun akhlak dan moral calon generasi penerus bangsa.Kini lembaga pendidikan Al-Quran berupa TKQ/TPQ atau sejenisnya telah cukup eksis.Dengan disahkannya PP No. 55 Tahun 2007 tentang pendidikan agama dan pendidikan keagamaan,makin memperkokoh keberadaan lembaga pendidikan Al-Quran ini,sehingga menuntut penyelenggarannnya untuk lebih professional.

Taman Pendidikan Al-Quran (TPQ) adalah suatu lembaga yang bergerak di bidang kegiatan-kegiatan agamis,begitupun seyogyanya taman pendidkan Al-Quran (TPQ) yang ada di Kelurahan Pagar Dewa yang seharusnya merupakan lembaga yang sangat tepat untuk mengembangkan syi ar Islam dalam hal pendalaman membaca Al-Qurean dengan baik dan benar dan kegiatan agama lainnya sesuai dengan visi, misi,dan tujuan dari taman pendidikan AlQuran tersebut.Keterampilan membaca Al-Quran yang baik dan benar atau lebih dikenal dengan istilah mengaji merupakan keterampilan penting pada fase awal guna memahami isi kandungan Al-Quran.Mengaji juga memiliki keterkaitan erat dengan ibadah-ibadah ritual kaum muslim,seperti pelaksanaan shalat,haji dan kegiatan-kegiatan lainnya.

Menghafal ayat-ayat Al-Qur an juga memiliki banyak manfaat bagi setiap orang,anakanak diharapkan mampu mengamalkan setiap ayat-ayat yang dihafal ke dalam shalat baik yang lima waktu atau shalat sunah lainnya.Selain mengamalkan ayat-ayatnya juga diharapkan mampu mengamalkan isi kandungan di dalam ayat-ayat yang telah dihafal,baik itu berbentuk menjauhi larangan maupun mematuhi perintah yang diterangkan oleh Al-Quran.Kemampuan menghafal anak juga dapat dipengaruhi oleh beberapa faktor dan tidak berbeda dengan faktor-faktor yang

${ }^{4}$ Wawancara Jumuhur,tanggal 10 Agustus 2021 di dusun Jorong desa Sikur Barat. 
mempengaruhi belajar pada umumnya yaitu faktor internal dan faktor eksternal.Faktor internal yaitu yang berasal dari dalam diri anak baik fisik ataupun psikis.Adapun faktor eksternal yaitu faktor yang berasal dari luar diri anak ataupun lingkungan. ${ }^{5}$

Mengetahui pentingnya meningkatkan kualitas bacaan al-Qur'an pada tanggal 8 juni 2021 kami para pemuda dan pemudi dusun Jorong Desa Sikur Barat membentuk sebuah lembaga Tahfidz yang bernama Lembaga Tahfidz dan Kajian Al-Qur'an Nurul Islam dengan jumlah santri kurang lebih 86 orang, jumlah pengurus sekitar 31 orang. Santri melakukan kegiatan rutin pada dua waktu yaitu untuk setoran hafalan dilakukan pada waktu sore dari hari senin sampai jum'at dan kegiatan murajaah dilakukan setelah selesai sholat subuh setiap hari dan dilanjutkan dengan kajian-kajian ilmu dasar agama. Selain kegiatan ini pengurus juga mengadakan kegiatan mingguan yaitu berzanji pada malam rabu dan hiziban pada malam jum'at. Setelah adanya lembaga ini santri terlihat semangat dalam mengaji, menghafal, dan mempelajari ilmu-ilmu agama, banyak diantara santri yang melampaui target, yang awalnya kami menargetkan setoran hafalan 3-5 ayat dalam satu hari namun banyak dari santri yang dalam satu hari bisa menyetorkan hafalannya sampai 10 ayat bahkan 15 ayat, sehingga dalam waktu satu bulan ada yang sudah hafal 1 juz. Masyarakat sangat senang melihat anak-anak mereka semangat dalam menghafal, sejak ada lembaga ini santri juga rajin melakukan sholat berjamaah di masjid hampir setiap waktu sholat.

Dalam meningkatkan kualitas hafalan pengurus menggunakan metode murajaah agar para santri tidak hanya menghafal saja namun harus tetap menjaga dan memperkuat hafalannya karena dengan murajaah bisa meningkatkan kualitas hafalan.

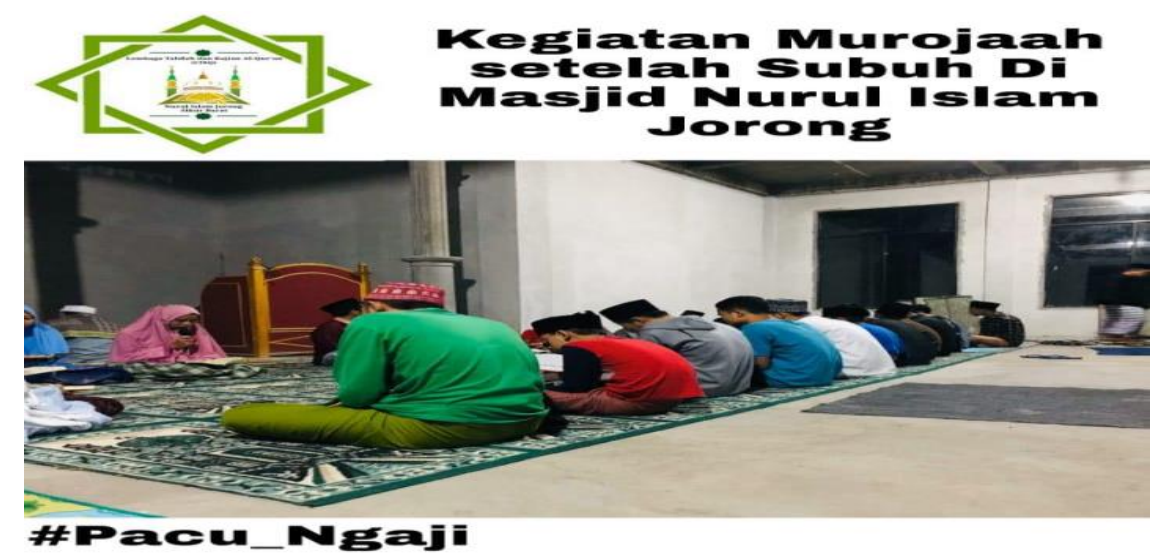

Setiam Hari

Gambar 1. Kegiatan murajaah setelah sholat subuh. ${ }^{6}$

\footnotetext{
${ }^{5}$ Juwi Jayanti"Peran TPQ Dalam Meningkatkan Kualitas Kemampuan Baca Al-Qur'an Pada Anak di TPQ ArRahman Kelurahan Pagar Dewa Kota Begkulu”.(Bengkulu,Skripsi agustus 2018).

${ }^{6}$ Kegiatan murajaah setelah selesai sholat subuh dilaksanakan setiap hari di dusun Jorong desa Sikur Barat
} 
Adapun kajian subuh yang dilakukan bertujuan untuk membantu santri dalam memahami dasar-dasar ilmu agama terutama yang berkaiatan dengan kehidupan sehari-hari karena belajar ilmu agama sangat penting terutama di usia dini.
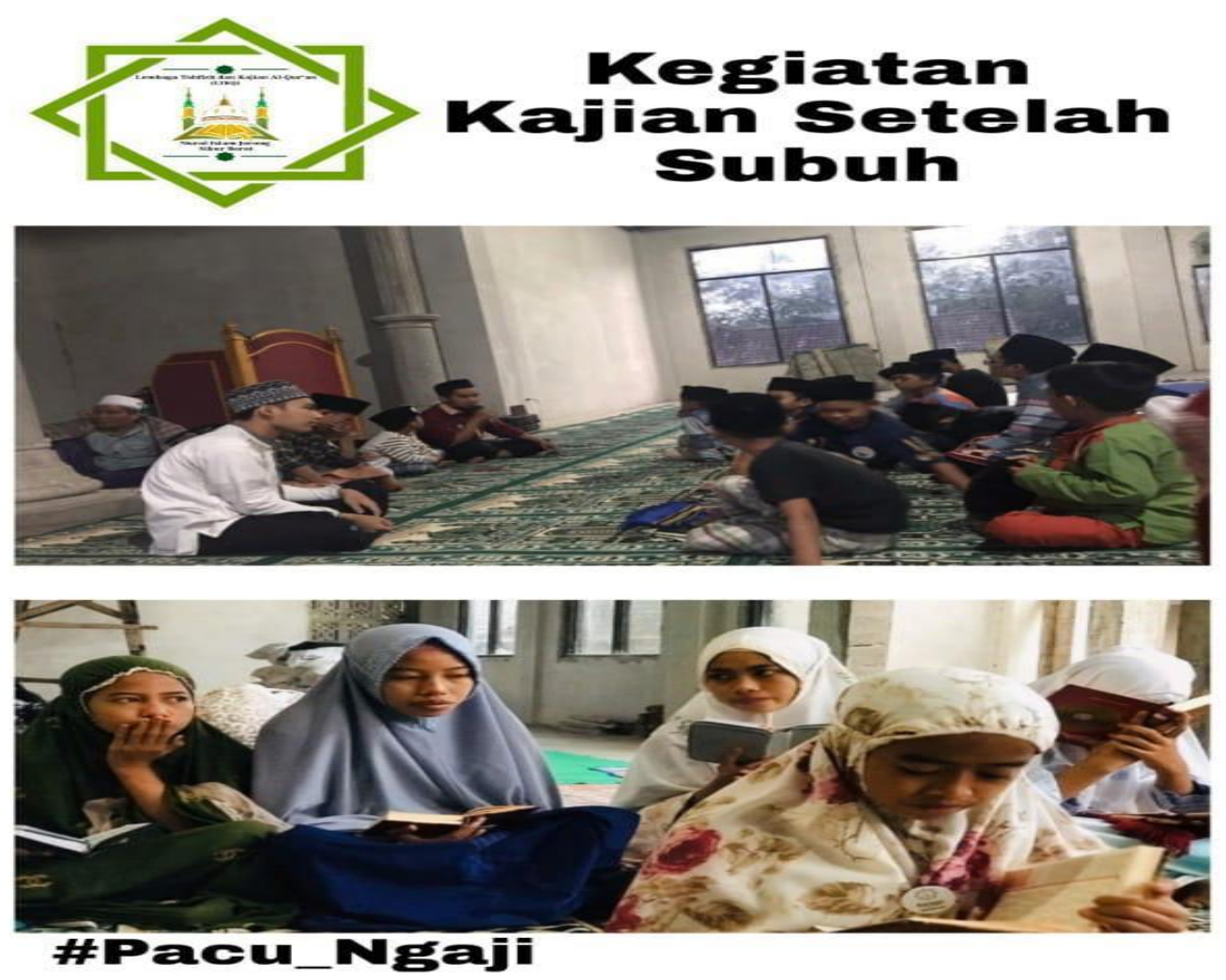

\section{Setian riari}

Gambar 2. Kegiatan kajian setelah sholat subuh. ${ }^{7}$

${ }^{7}$ Kegiatan kajian setelah sholat subuh dilaksanakan setiap hari di dusun Jorong desa Sikur Barat 


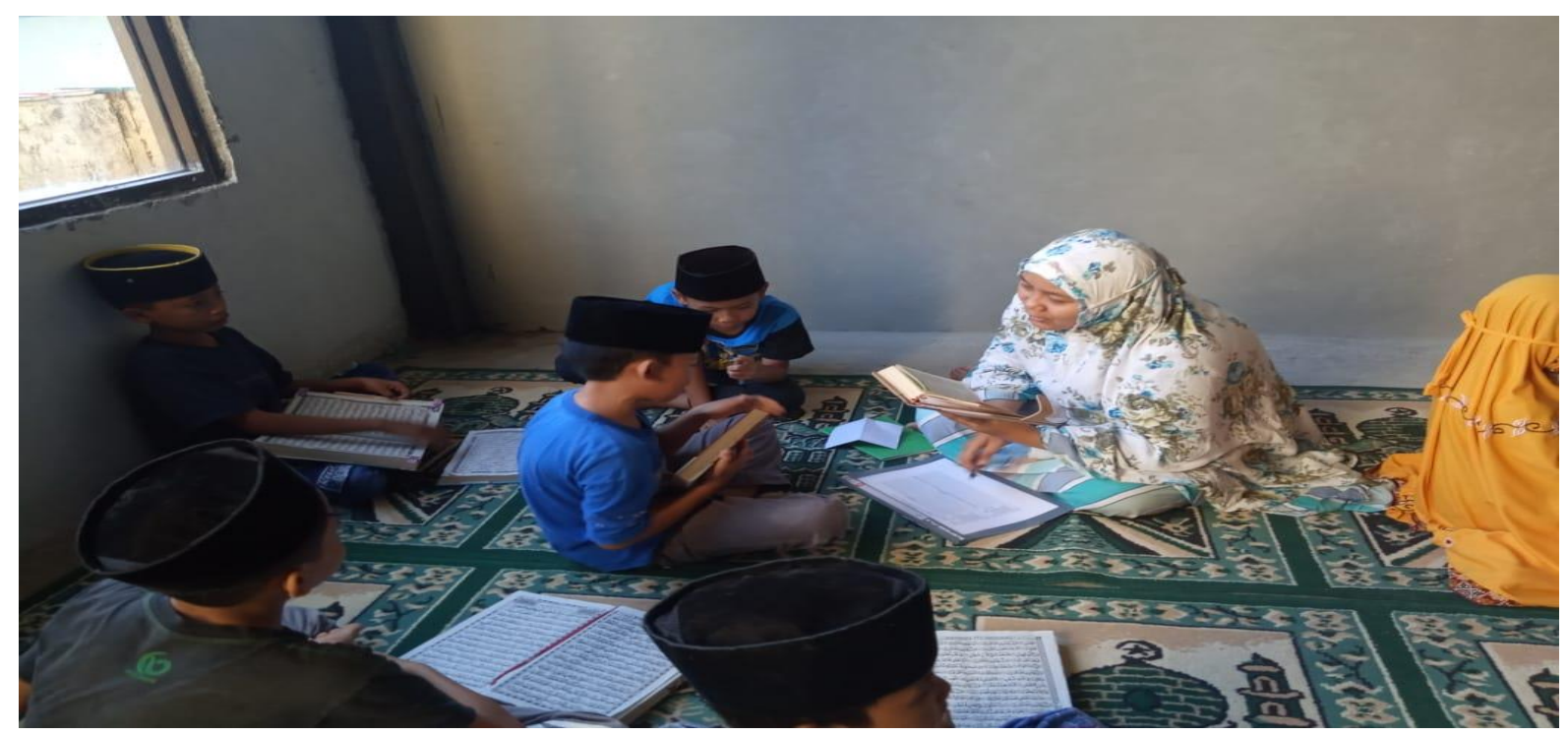

Gambar 3. Setoran hafalan yang dilakukan selesai sholat asar. ${ }^{8}$

Santri wajib menyetor hafalan minimal 3 ayat setiap hari kepada pengurus atau ustadz dan ustadzahnya masing-masing.

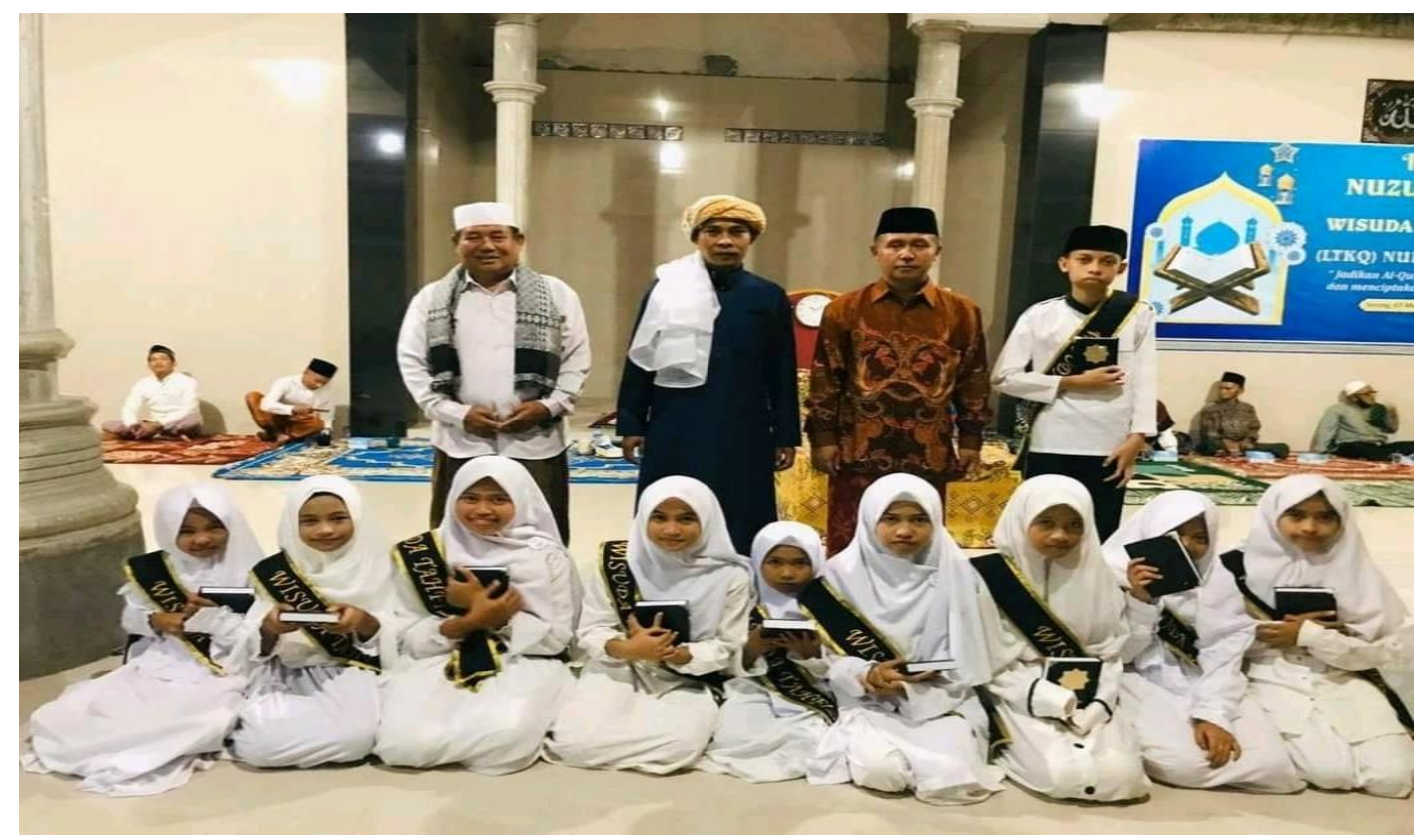

Gambar 4. Acara wisuda tahfidz. ${ }^{9}$

\footnotetext{
${ }^{8}$ Kegiatan setoran hafalan dilaksanakan setiap hari senin sampai jumat di dusun Jorong desa Sikur Barat

${ }^{9}$ Acara wisuda tahfidz dilaksanakan 2021 di dusun Jorong desa Sikur Barat
} 
Sebagai apresiasi pengurus Lembaga Tahfidz dan Kajian Al Qur'an Nurul Islam kami menbuat acara wisuda untuk santri yang sudah menghafal 5 juz Al Qur'an. Dalam Islam, tidak perlu takut ketika menghafal ilmu. Sebab menurut kitab Ta'lim Muta'allim oleh Syekh Zarnuji memberikan sejumlah tips agar hafalan menjadi kuat.

\section{Meninggalkan maksiat}

Menurut para ulama, maksiat dapat membuat hati seseorang menjadi gelap sehingga sulit menerima ilmu. Oleh sebab itu, hafalan bisa cepat hilang dari kepala apabila sering melakukan maksiat yang jelas-jelas dilarang dalam agama. Imam Syafii pernah mengadu pada gurunya tentang sulitnya menghafal yang dihadapinya. Dalam syairnya Imam Syafii berkata,"Aku mengadukan hafalanku yang buruk kepada Waki' (gurunya),lalu ia menasihatiku agar aku meninggalkan maksiat. Sebab sesungguhnya hafalan merupakan anugerah dari Allah,dan anugerah dari Allah tidak akan diberikan kepda orang yang bermaksiat."

\section{Bersungguh-sungguh}

Sebuah ungkapan yang tidak asing lagi bagi kita berbunyi,"Man Jadda Wajada"(Barang siapa yang bersungguh-sungguh pasti dapat). Maka dari itu,siapa saja yang memiliki tekad kuat dan berusaha semaksimal mungkin untuk menghafal pelajaran pasti akan bisa pada akhirnya.

\section{Menghafal setelah salat malam}

Rasulullah SAW dalam berbagai hadis mengatakan bahwa salah satu waktu tebaik untuk beribadah adalah saat sepertiga malam terakhir, waktu di mana kita disunahkan salat malam (tahajud). Karena itulah di waktu tersebut tepat dimanfaatkan untuk menghafal suatu ilmu karena pikiran dan suasana pasti lebih tenang.

\section{Memperbanyak membaca Al-Qur'an}

Jika sering lupa merupakan suatu penyakit,maka sering membaca Al-Qur'an adalah solusi tepat sebagai obatnya.Imam Nawawi dalam kitab Al-Adzkar berpendapat bahwa membaca Alquran dengan melihatnya langsung dapat meningkatkan kekuatan hafalan.

\section{Menyedikitkan makan}

Lebih baik lagi jika menyedikitkan makan ini dalam bentuk berpuasa.Secara psikis, terkadang ide-ide brilian dapat muncul ketika seseorang tengah dalam keadaan lapar karena harus berpikir untuk melakukan sesuatu.Di saat-saat lapar inilah Syekh Zarnuji menyebut dapat meningkatkan hafalan.

\section{Bersiwak}

Rahmanita \& Jamhuri (2021), Dampak kebijakan pengalihan.........

| Vol. 01, No.02, 2021 | h. 101 
Bersiwak menjadi suatu amalan sunah yang sangat dianjurkan bagi umat muslim khususnya dalam mengerjakan suatu ibadah termasuk mencari ilmu. Rasulullah bersabda,"Siwak membersihkan gigi dan ini menyenangkan Allah.Setiap kali Jibrill mengunjungiku, dia menyuruhku menggunakan siwak, hingga aku pun khawatir bahwa menggunakan siwak diwajibkan. Seandainya tidak khawatir akan membebani (merepotkan) umatku, aku akan mewajibkannya." (HR Bukhari dan Muslim).

\section{Memperbanyak mengkonsumsi madu}

Disebutkan dalam berbagai riwayat bahwa madu adalah obat segala jenis obat karena cairan yang dihasilkan lebah ini terjamin kesucian dan kebersihannya.

Rasulullah saw bersabda,"Madu adalah penyembuh bagi semua jenis sakit dan Al-Qur'an adalah penyembuh bagi semua kekusutan pikiran (sakit pikiran). Maka aku sarankan bagimu kedua penyembuh tersebut, Al-Qur'an dan madu." (HR. Bukhari).

\section{Memperbanyak makan anggur}

Anggur merupakan buah yang istimewa dalam Islam bahkan diabadikan Allah dalam salah satu firman-Nya."Dia menumbuhkan bagi kamu dengan air hujan itu tanam-tanaman, zaitun, kurma, anggur dan segala macam buah-buahan. Sesungguhnya pada yang demikian itu benar-benar ada tanda (kekuasaan Allah) bagi kaum yang memikirkan." ( QS. An Nahl: 11). ${ }^{10}$

\section{Kesimpulan}

Memberi pengetahuan dan edukasi tentang al-Qur'an sangatlah penting bagi anak usia dini. Semangat mencintai al-Qur'an pada anak usia dini dapat dijadikan acuan bagi para pendidik dan orangtua untuk menemukan metode yang efektif dan kreatif untuk mempelajari dan menghafal al-Qur'an Masa anak usia dini merupakan masa-masa pertumbuhan dan perkembangan dari berbagai aspek.Apa yang diberikan dan diajarkan menjadi penentu bagi tahapan perkembangan. Dan setelah adanya lembaga ini para pemuda pemudi jadi tau sampai mana kemampuan dan pengetahuan santri tentang Al Qur'an,karena adanya lembaga ini kualitas bacaan dan hafalan Al Qur'an santri meningkat bukan hanya itu santri juga rajin dalam beribadah. Respon masyarakat juga sangat positif dengan adanya lembaga dan program tahfidz ini masyarakat bangga dengan anak-anak mereka yang mampu menghafal Al-Qur'an.

\section{Ucapan Terimakasih}

${ }^{10}$ Rini Astuti"Peningkatan Kemampuan Membaca Al-Qur'an Pada Anak ADD Melalui Metode Al-Barqy Berbasis Applied Behavior Analysis”.Journal Pendidikan Usia Dini,vol.o7. November 2013

Rahmanita \& Jamhuri (2021), Dampak kebijakan pengalihan.........

| Vol. 01, No.02, 2021 | h. 102 
Kami ucapkan terima kasih kepada LP2M dan masyarakat dan tokoh agama yang sudah mendukung para pemuda dan pemudi dalam mendirikan Lembaga Tahfidz dan Kajian AlQur'an ini,terima kasih juga kepada bapak dan ibu donatur yang sudah memberikan bantuan berupa uang dan Al-Qur'an yang bisa digunakan untuk keperluan santri dan lembaga.

\section{Daftar Pustaka}

Julianto,Teguh Arafah.2020.Metode menghafal dan Memahami Al-Qur'an Bagi Anak Usia Dini. Journal of Islamic Education juli 2020 vol.03.

Hidayah,Aida.2017.Metode Tahfid Al-Qur'an Anak Usia Dini.Journal Studi Ilmu-ilmu AlQur'an dan Hadits januari 2017 vol.01.

Jayanti Juwi.2018.Peran TPQ Dalam Meningkatkan Kualitas Kemampuan Baca Al-Qur'an Pada Anak di TPQ Ar-Rahman Kelurahan Pagar Dewa Kota Begkulu. Skripsi agustus 2018.

Nurkhaeriyah.2019. Metode Menghafal Al-Qur'an Pada Anak Usia Dini Di Rumah Tabfidz. Qur'an At-Taqwa Kota Cirebon.Journal Jendela Bunda maret 2019 vol.07.

Astuti Rini.Peningkatan Kemampuan Membaca Al-Qur'an Pada Anak ADD Melalui Metode AlBarqy Berbasis Applied Behavior Analysis.Journal Pendidikan Usia Dini November 2013 vol.07 